\title{
Anny Lazarus and Laurent Septier, Art contemporain. Pékin en 11 parcours
}

(Contemporary art in Beijing through 11 trips), Marseille, Images En Manœuvres Éditions, 2010, 287 pp.

\section{Emmanuel Lincot}

Translator. N. Jayaram

\section{OpenEdition}

\section{Journals}

Electronic version

URL: http://journals.openedition.org/chinaperspectives/5490

DOI: 10.4000/chinaperspectives.5490

ISSN: 1996-4617

\section{Publisher}

Centre d'étude français sur la Chine contemporaine

\section{Printed version}

Date of publication: 1 January 2011

Number of pages: 97

ISSN: 2070-3449

\section{Electronic reference}

Emmanuel Lincot, "Anny Lazarus and Laurent Septier, Art contemporain. Pékin en 11 parcours »,

China Perspectives [Online], 2011/1 | 2011, Online since 30 March 2011, connection on 23 September 2020. URL : http://journals.openedition.org/chinaperspectives/5490 ; DOI : https://doi.org/10.4000/ chinaperspectives.5490

This text was automatically generated on 23 September 2020

(c) All rights reserved 


\section{Anny Lazarus and Laurent Septier, Art contemporain. Pékin en 11 parcours}

(Contemporary art in Beijing through 11 trips), Marseille, Images En Manœuvres Éditions, 2010, 287 pp.

\section{Emmanuel Lincot}

Translation : N. Jayaram

This highly useful work is a concise compendium of Chinese contemporary art. It has two parts: one focusing on the historical and cultural bases of chinese contemporary art, and the other devoted to Beijing, where it is most active and diversified. This is as yet the only practical guide in French offering an unprecedented selection of places and trips. Despite the book's awkward construction (the format as well as the binding make for uncomfortable reading), its list of the capital's most important galleries is exhaustive. Their names in Chinese characters and access facilities are clearly set out (p. 95). Brief accounts of the founders and their orientations in artistic programming are given. It is striking to note the extraordinary profusion of exhibition venues. Of course there are the galleries (at Dashanzi, the

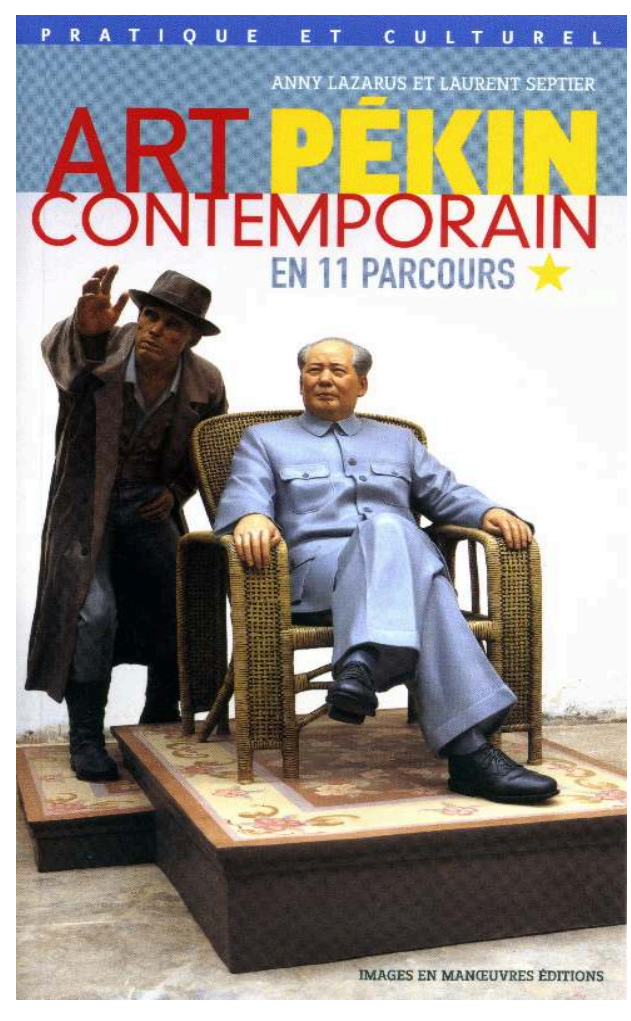
former military equipment factory, and at 
Caochangdi), but also foundations, research and archival centres at sponsoring bodies, and/or major scientific institutions (and noted people such as Pearl Lam, Guy and Myriam Ullens, Gao Minglu, Ai Weiwei ${ }^{1} \ldots$..), private museums, artists' workshops, and residences dedicated to hosting foreign multimedia artists. Not long ago threatened with expulsion, these massive centres of contemporary art in eastern Beijing (near the international airport) now draw the regime's solicitations. President Hu Jintao has included the promotion of these centres in his vision for developing "a harmonious society."

2 There have been few studies so far on this complex phenomenon of rehabilitating former industrial wastelands into gleaming and sophisticated venues for global exchanges in China. The exceptions are the studies by Hermance de La Bastide ${ }^{2}$ (Sciences Po Paris) and Wu Hung ${ }^{3}$ (University of Chicago). No doubt it would have been unwieldy to include these references in the book, but the initiative of Anny Lazarus and Laurent Septier is praiseworthy for having compiled an exhaustive list of Internet sites that would help keep tabs on artistic events in the capital's outer zones. An historical account of Chinese contemporary art in the book's first part helps those unfamiliar with it to learn of the multiplicity of visual arts that proliferated following the reforms ushered in by Deng Xiaoping. Previously unpublished translations on the system of fine arts and the regime's censorship notify the readers of an interpretation of China's artistic scene that they might - rightly or wrongly - deem liberal (p. 30). Finally, the mostly new illustrations testify to commendable documentation research.

Some reservations nevertheless: neither the artists' names nor the titles of their works are given in Chinese characters. China's historic and political background is set out in sometimes dismissive argumentation: No, Beijing was not by any yardstick the only city where "the modern destiny of China and of communism played out with the May Fourth Movement of 1919" (p. 13). Communism was by no means at the heart of modernism, nor was its birth in any special way linked to Beijing, for a simple reason (a matter of timing): The Chinese Communist Party was formed clandestinely two years after the May Fourth Movement in Shanghai's French concession.

It is important to note, as Lazarus and Septier do, that it was in the context of the 1980s reforms that Erwin Panofsky, Rudolf Arnheim, and Ernst Gombrich (p. 49), as well as Jacques Derrida, Roland Barthes, and Michel Foucault, were translated into Chinese for the first time. Access to major thinkers was essential for the emergence of indigenous art criticism. With major mentors (Li Xianting, Pi Li, Fei Dawei, Hou Hanru ${ }^{4} .$. ), art criticism accompanied the extraordinary artistic flowering (political Popart, cynical Art, Neo-dadaism, emerging artists' works, Performance art, Video...). Fuelled by publicity, art criticism led to a conceptual counter-formulation that, in the context of virulent criticism of post-colonialism and profound challenges to Western criteria of modernity, helped China and its artists to establish a discursive strategy. Art criticism played a major role in the success Chinese artists have enjoyed over the past two decades through their participation in major international artistic events (Venice, Lyon, Yokohama...) and through the spectacular rise in the prices they have come to command. Globalisation has contributed to the emergence of an art market. A relentless flow of goods, people, and information links China to its worldwide diaspora. These interactions have led artists and art professionals to define not only new "lifestyles," that is to say new forms of affirmation and differentiation of social statuses 
in the Weberian sense, but also categories of thought and ways of doing that profoundly change the appreciation of a work.

An outstanding example mentioned in the book concerns the Rent Collection Courtyard (p. 63). Formed on the eve of the Cultural Revolution in 1965 by a group of Sichuan artists, this sculptural ensemble (applying realist-socialist norms) was wholly reworked in 1999 by Cai Guoqiang ${ }^{5}$ during the $48^{\text {th }}$ Venice Biennale. Threatened with a plagiarism suit, he crossed a threshold by questioning the meaning of the term "citation" and drawing attention to a problem that was philosophical as much as monetary in the legal sense, in all aspects of the respect for intellectual property.

To conclude, the work of Lazarus and Septier is a must for art lovers or for those simply curious to know about the Beijing art scene. One can expect the two to come up with more such guides in the near future devoted to artistic exploration in other centres in China.

\section{NOTES}

1. Pearl Lam and Guy and Myriam Ullens are collectors in Shanghai and Beijing respectively; Gao Minglu is art historian, and Ai Weiwei is an artist and activist.

2. Hermance de La Bastide, "Art et phénomène de regroupement à Pékin" (Art and relocation phenomenon in Beijing),in Emmanuel Lincot (ed.), Arts, propagandes et résistances en Chine, Paris, You Feng, 2008, pp. 38-52.

3. Wu Hung, Contemporary Chinese Art: Primary Documents, New York, MOMA, 2010.

4. Li Xianting is credited with coining the expression "cultural popart"(wenhua popu)and organising major exhibitions (Xing Xing and the Chinese pavilion at the 45th Venice Biennale in 1995). Pi Li runs The Universal Studio at Caochangdi and is an art critic like his father Pi Daojian, an ardent promoter of emerging artists' works. Fei Dawei - a French citizen of Chinese origin - is a curator. He earned fame by curating the "Chine demain pour hier" (China tomorrow for yesterday - 1990) exhibition. Hou Hanru was curator of the Lyon Biennale (2010).

5. Born in 1957, mixed media artist Cai Guoqiang has specialised in pyrotechnics. He directed the Opening Ceremony special effects at the 2008 Beijing Olympics.

\section{AUTHORS}

\section{EMMANUEL LINCOT}

Director of the Contemporary China Studies chair at the Catholic Institute, Paris. 